\title{
The carbon isotopes ratio in small lakes bottom sediments located in the forest-steppe and steppe zones of southern Siberia
}

\author{
Vera Strakhovenko ${ }^{1,{ }^{*}, \text { Ekaterina Ovdina }}{ }^{1}$, and Georgy Malov ${ }^{1}$ \\ ${ }^{1}$ Sobolev Institute of Geology and Mineralogy of the Russian Academy of Sciences (IGM SB RAS), \\ 630090, Novosibirsk, Russia
}

\begin{abstract}
Isotopic variations of carbon of the carbonates and organic matter in bottom sediments of lakes of two lake systems located in the South of Siberia are studied: Baraba (Baraba steppes) and Tazheran (Tazheran steppes). Isotopic studies of $\delta^{13} \mathrm{C}$ carbonates and organic matter of the lacustrine bottom sediments of the Tazheran and Baraba systems indicate two main mechanisms of authigenic carbonates formation: chemogenic deposition and biochemogenic deposition due to bacterial destruction of organic matter. The dependence of the $\delta^{13} \mathrm{C}_{\text {org }}$ and $\delta^{13} \mathrm{C}_{\mathrm{carb}}$, the degree of water salinity is not revealed. Forms by chemogenic carbonates are similar to water isotopic values, i.e. with dissolved bicarbonate - ion reservoir. However, in most of the studied lakes the light isotopic composition $\delta^{13} \mathrm{C}_{\text {carb }}$ was revealed, as carbonates are formed in the environment with a high content of isotope-light $\mathrm{CO}_{2}$ formed by the oxidation of carbon dioxide emitted by bacteria-decomposers in the mineralization process of the original organic matter in the stagnant waters in the anaerobic environment.
\end{abstract}

\section{Introduction}

The application of hydrogen, oxygen and carbon stable isotopes is widely used in the study of hydrogeochemical processes occurring in water reservoirs [1;2]. Carbonate and organic carbon isotope composition of lacustrine bottom sediments keep important genetic information. Modern organic carbonate deposits are formed in lakes with a wide range of water mineralization value (from fresh to brines) and in all landscape zones of Southern Siberia. The geochemical landscape and low-flow regime of the Siberian small lake waters favor massive growth of living organisms. The anaerobic environment at the water/sediment boundary promotes the burial of organic matter as terrigenous material builds up. The aim of this work is to study the isotopic carbon variations of lacustrine bottom sediment carbonates and organic matter of two lake systems located in Southern Siberia.

\footnotetext{
* Corresponding author: strahova@igm.nsc.ru
} 


\section{Materials and methods}

Objects of the study are two lake systems: Baraba (Baraba steppe) and Tazheran (Tazheran steppe). Water, bottom sediments, lacustrine biota and associated sources were investigated. Two complementary approaches are combined in this context: a detailed study of a lake and a lake system characterized by compact arrangement under the same landscape, climatic, geologic and geochemical conditions. We selected the Tazheran system of small lakes on the western shore of Lake Baikal, on a rocky plateau (Ol'khon area) with arid conditions (Tazheran steppes, 100-250 mm/yr) and Baraba system of small lakes of the Om'-Tatarsk-Vasyugan inter-ridge lowerings with semi-arid conditions (Baraba steppe, $250-400 \mathrm{~mm} / \mathrm{yr}$ ) [3; 4; 5]. Along with similar landscape, climatic, geologic, and geochemical conditions of recent evolution, the lakes in each system have the same source of water.

Water and bottom sediments were collected (in August 2003, 2005, 2007, 2010, 2011, $2012,2014,2016,2017)$ in the central part of the water reservoirs from a catamaran. Bottom sediments were selected using a sampler with a cylindrical vacuum lock to a depth of $2 \mathrm{~m}$. Visual and lithological description of core samples and analysis of the unstable parameters of water (temperature, $\mathrm{pH}$, Eh, and contents of oxygen and the sulfide ion) were carried out in situ. The core samples were studied layer-by-layer at intervals of $1-2 \mathrm{~cm}$. The sediments have studied by a set of geological, geochemical, petrographical, and mineralogical methods $[3 ; 4 ; 5]$. The isotopic composition of oxygen and carbon was measured with a Finnigan MAT-253 mass spectrometer with sample preparation on a Gas Bench II line by standard methods in the Sobolev Institute of Geology and Mineralogy (Novosibirsk, Russia). The isolation of the limestone organic matter was carried out by carbonate dissolution in solution $1 \mathrm{~N} \mathrm{HCl}$. The accuracy of the carbon and oxygen carbonate material measurements was controlled by the NBS19 international standard $(\delta 13 \mathrm{C}=$ $+1.9 \%, \delta 18 \mathrm{O}=-2.2 \%$ ) and amounted to $0.1 \%$ for $\delta 13 \mathrm{C}$ and $\delta 18 \mathrm{O}$ values. The accuracy of carbon isotopic composition measurements in organic matter was monitored using an international standard NBS $22(\delta 13 \mathrm{C}=-30.03 \%)$. The error of the obtained isotope data was $0.5 \%$. All $\delta$ values for carbon and oxygen are given in ppm relative to the PDB standard.

\section{Results}

By the level of water mineralization, the studied lakes range from fresh to slightly saline (Table 1). The water of all lakes is alkaline $(\mathrm{pH} 7.9$ - 9.6). The water of fresh and saline lakes is hydrocarbonate-sodium or hydrocarbonate-sodium-magnesium. Sometimes the composition of saline lake water is chloride- hydrocarbonate-sodium and chloride-sulfatesodium.

Data on the ratio of oxygen and hydrogen isotopes in the water of the studied springs and lakes indicate that the water is mainly of meteoric origin. All established isotope ratios $\delta \mathrm{D}$ and $\delta^{18} \mathrm{O}$ in the studied lake waters are located near the Craig line. Small variations in the isotopic composition of lake waters located at a short distance from each other correspond to the kinetic isotopic effects of different evaporation of lake waters. Organic matter and authigenic carbonates accumulate in the bottom sediment but in different amounts and different stoichiometric composition (Table 2). Previously, we established that in lakes there is a modern authigenic mineral formation with the active participation of organic matter on 3 borders of the phase division: "water-atmosphere», "submerged algae and macrophytes» «water-bottom sediment». Minerals that decompose during the algae life can consist of chalcedony (diatoms), or form thin films on the primary frame of algae, consisting of fine-grained aragonite, Mg-sulfate and magnesium carbonates. Low-Mg 
calcite, aragonite and pyrite accumulate in the bottom sediment because of biochemogenic deposition. Bacteria and fungi activity that live in the bottom sediment (first $\mathrm{cm}$, large quantities) result in anaerobic degradation of the silt original organic matter, which in turn produces gases $-\mathrm{CO}_{2}, \mathrm{H}_{2} \mathrm{~S}, \mathrm{NH}_{3}$ etc. In lakes with a hydrocarbonate sodium content in water more than $4 \mathrm{~g} / \mathrm{l}$ the roundish micrograins of the Ca-excess dolomite and high-Mg calcite precipitate from water in the bottom sediment that contributes to the dissolution and disappearance of magnesium sulfates and carbonates (partially aragonite). The aragonite, low-Mg calcite and calcite are accumulated in all lakes with the different types of water. The formation of the calcite or aragonite aggregates is one of the most common cases of precipitation.

Table 1. Chemical composition and chemical parameters of water in small lakes of the studied systems.

\begin{tabular}{|c|c|c|c|}
\hline Lake & $\mathbf{p H}$ & TDS,g/l & Ion composition of waters (Kurlov formula) \\
\hline Khara-Nur & $7,9-8,3$ & 0,5 & $\frac{\mathrm{HCO} 378[\mathrm{SO} 422]}{\mathrm{Mg} 48 \mathrm{Na} 28[\mathrm{Ca} 24]}$ \\
\hline Gyzgi-Nur & $9,1-9,3$ & $0,8-1,3$ & $\frac{\mathrm{HCO} 362 \mathrm{SO} 433[\mathrm{Cl} 5]}{\mathrm{Mg} 59 \mathrm{Na} 35[\mathrm{Ca} 6]}$ \\
\hline Nukhu-Nur & $8,6-9$ & $1,1-1,9$ & $\frac{\mathrm{HCO} 355 \mathrm{SO} 438[\mathrm{Cl} 7]}{\mathrm{Mg} 51 \mathrm{Na} 43[\mathrm{Ca} 6]}$ \\
\hline Gurbi-Nur & $8,9-9,7$ & $9-11,2$ & $\frac{\mathrm{SO} 460 \mathrm{HCO} 329[\mathrm{Cl} 11]}{\mathrm{Na} 60 \mathrm{Mg} 40}$ \\
\hline Skalistoe & $9,2-9,5$ & $3,6-4,1$ & $\frac{\mathrm{SO} 453 \mathrm{HCO} 336[\mathrm{Cl} 11]}{\mathrm{Na} 53 \mathrm{Mg} 47}$ \\
\hline Kholbo-Nur & $8,8-9,5$ & $4,3-6,4$ & $\frac{\mathrm{SO} 477[\mathrm{Cl} 15 \mathrm{HCO} 38]}{\mathrm{Na} 53 \mathrm{Mg} 47}$ \\
\hline Shular-Nur & $9,1-9,6$ & $3,2-6,6$ & $\frac{\mathrm{SO} 479[\mathrm{Cl} 15 \mathrm{HCO} 36]}{\mathrm{Na} 51 \mathrm{Mg} 49}$ \\
\hline Tsagan-Tyrm & $8,6-9,1$ & $14,5-22,1$ & $\frac{\mathrm{Cl} 63 \mathrm{SO} 431[\mathrm{HCO} 36]}{\mathrm{Na} 76[\mathrm{Mg} \mathrm{24]}}$ \\
\hline Melkoe & $8,9-9,3$ & 8,8 & $\frac{\text { SO4 } 70[\mathrm{HCO} 321 \mathrm{Cl} 9]}{\mathrm{Mg} 60 \mathrm{Na} 40}$ \\
\hline Namshi-Nur & $8,9-9,2$ & $1,8-2,7$ & $\frac{\mathrm{HCO} 349 \mathrm{SO} 442[\mathrm{Cl} 9]}{\mathrm{Na} 57 \mathrm{Mg} 41}$ \\
\hline Barchin & $8,9-9,2$ & $0,4-0,6$ & $\frac{\mathrm{HCO} 380[\mathrm{Cl} 11 \mathrm{SO} 49]}{\mathrm{Na} 57 \mathrm{Mg} 30[\mathrm{Ca} 13]}$ \\
\hline Jrgol’ & $8,4-8,8$ & $0,3-0,4$ & $\begin{array}{c}\mathrm{HCO} 390[\mathrm{Cl} 10] \mathrm{l} \\
\mathrm{Na} 54[\mathrm{Mg} 24 \mathrm{Ca} 22]\end{array}$ \\
\hline Peschanoe & $9,2-9,6$ & $3,1-3,4$ & $\frac{\mathrm{HCO} 346 \mathrm{Cl} 35[\mathrm{SO} 421]}{\mathrm{Na} 83[\mathrm{Mg} \mathrm{17]}}$ \\
\hline Large Kajli & $8,8-9,6$ & $0,6-0,9$ & $\frac{\mathrm{HCO} 345 \mathrm{Cl} 37[\mathrm{SO} 4 \mathrm{18}]}{\mathrm{Na} 79[\mathrm{Mg} 13 \mathrm{Ca} 8]}$ \\
\hline Zhiloe & $8,6-9,0$ & $0,8-1,0$ & $\frac{\mathrm{HCO} 344 \mathrm{Cl} 35[\mathrm{SO} 421]}{\mathrm{Na} 81[\mathrm{Mg} 13 \mathrm{Ca} 6]}$ \\
\hline
\end{tabular}

The total contribution of the biota to the expelled water is $10-12 \%$. The other constituents of the balance are the reburial of detritus of the previous years (resuspended detritus), allochthonous removal of organic matter from the catchment area, and the mineral constituent. An active role in the formation of sapropels belongs to microorganisms.

The studied lakes are characterized by the widespread occurrence of bacteria of the genus Sphaerotilus, which reduce Fe actively, and sulfate-reducing eubacteria, which play the leading role in the formation of hydrogen sulfide in nature and in the deposition of sulfide minerals. Pyrite was found in all the bottom sediments of the studied lakes [5]. 
Table 2. Isotopic composition of carbon $\left(\delta^{13} \mathrm{C}\right)$ and oxygen $\left(\delta^{18} \mathrm{O}\right)$ in carbonates and organic matter of lacustrine bottom sediments in forest-steppe and steppe zones of Siberia.

\begin{tabular}{|c|c|c|c|}
\hline $\begin{array}{c}\text { The description of the bottom sediments, } \\
\text { mineralogical composition }\end{array}$ & $\begin{array}{c}\delta^{13} C_{\text {carb}}(\mathrm{VP} \\
\text { DB }), \%\end{array}$ & $\begin{array}{c}\delta^{18} \text { O(vSMo } \\
\text { w), \%o }\end{array}$ & $\begin{array}{c}\delta^{13} \mathrm{Corg}_{\mathrm{org}}(\mathrm{VP} \\
\mathrm{DB}) \% \%\end{array}$ \\
\hline \multicolumn{4}{|c|}{ bottom sediments in the Tazheran lakes } \\
\hline Khara-Nur, ash-76 \%, low-Mg Cal 74\%, & $-7,3$ & 19,8 & $-29,3$ \\
\hline Gyzgi-Nur, ash-75\%, intermediate-Mg Cal - $86 \%$ & $-0,9$ & 23 & $-25,7$ \\
\hline $\begin{array}{lclll}\begin{array}{l}\text { Nukhu-Nur, ash-77 \%, } \\
\text { intermediate-Mg Cal-44\%, }\end{array} & \text { low-Mg } & \text { Cal and } & \text { al } \\
\end{array}$ & $-2,2$ & 22,7 & $-24,1$ \\
\hline $\begin{array}{l}\text { Gurbi-Nur, ash-73\%, high-Mg Cal, excess-Ca Dol, - } \\
78 \%\end{array}$ & $-3,07$ & 21,4 & $-26,4$ \\
\hline $\begin{array}{l}\text { Skalistoe, ash-71\%, high-Mg Cal, intermediate-Mg } \\
\text { Cal, excess-Ca Dol and aragonite-34\%, low-Mg Cal } \\
\text { and monohydrocalcite } 2 \%\end{array}$ & -6 & 23 & $-24,6$ \\
\hline $\begin{array}{l}\text { Kholbo-Nur, ash-78 \%, high-Mg Cal - } 34 \% \text {, } \\
\text { intermediate-Mg Cal, - } 25 \% \text {, low-Mg Cal } 24 \% \text {, } \\
\text { aragonite }-15 \%\end{array}$ & $-6,3$ & 21,1 & $-23,8$ \\
\hline $\begin{array}{l}\text { Shular-Nur, ash-76 \%, intermediate-Mg Cal, - } 83 \% \text {, } \\
\text { low-Mg Cal - } 17 \%\end{array}$ & $-4,2$ & 23,4 & $-28,6$ \\
\hline $\begin{array}{l}\text { Tsagan-Tyrm, ash-71 \%, high-Mg } \mathrm{Cal}-25 \% \text {, } \\
\text { intermediate-Mg Cal, }-11 \% \text {, excess-Ca Dol } 31 \% \text {, } \\
\text { low-Mg Cal }-23 \%\end{array}$ & $-23,6$ & 15,8 & $-13,8$ \\
\hline $\begin{array}{l}\text { Melkoe, ash - } 76 \% \text {, low-Mg Cal - 15\%, high-Mg } \\
\text { Cal - } 85 \%\end{array}$ & $-6,9$ & 21,1 & $-24,5$ \\
\hline $\begin{array}{l}\text { Namshi-Nur, ash-86 \%, low-Mg Cal and } \\
\text { intermediate-Mg Cal, } 16 \%, \text { monohydrocalcite } 1 \%\end{array}$ & $-3,9$ & 21,3 & $-26,4$ \\
\hline \multicolumn{4}{|c|}{ bottom sediments in the Baraba lakes } \\
\hline Barchin, ash $-42 \%$, low-Mg Cal & -12 & 19,2 & $-25,2$ \\
\hline Jrgol', ash $-38 \%$, low-Mg Cal & -17 & 12,3 & $-25,4$ \\
\hline Peshanoe, ash $-41 \%$, low-Mg Cal & $-28,5$ & 14,7 & $-23,4$ \\
\hline Large Kajli, ash - $44 \%$, low-Mg Cal & $-21,8$ & 11,2 & $-27,2$ \\
\hline Zhiloe, ash - $62 \%$, low-Mg Cal & -11 & 20,4 & $-29,1$ \\
\hline
\end{tabular}

Note: Cal - calcite; Dol - dolomite

Standart NBS-22 oil (50 copies) $\boldsymbol{\delta}^{\mathbf{1 3}} \mathbf{C V P D B}_{\text {VPD }}=\mathbf{- 3 0 . 0 3} \pm \mathbf{0 . 2}$

Standart NBS-19 limestone ( 40 copies) $\boldsymbol{\delta}^{\mathbf{1 3}} \mathbf{C V P D B}_{\mathrm{VPD}}=+\mathbf{1 . 9 5} \pm \mathbf{0 . 1} ; \delta^{18} \mathrm{OVSMOW}_{\mathrm{v}}=+\mathbf{2 8 . 6 5} \pm \mathbf{0 . 1}$

It was established that the values of the carbon organic matter isotopic composition of lacustrine bottom sediments vary within $\delta^{13} \mathrm{C}$ (from $-23,8 \%$ to $-29,3 \%$ ) for Tazheran system and $\delta^{13} \mathrm{C}$ (from $-23,4 \%$ to $-29,1 \%$ ) for Baraba system. The exception is the value of the bottom sediment carbon organic matter isotopic composition the of lake Tsagan-Tyrm (Tazheran system) $\delta^{13} \mathrm{C}--13,8 \%$.

This proves that a significant component of organic material accumulating in the sediment is formed with the direct participation of microorganisms [1]. Relatively small fluctuations of $\delta^{13} \mathrm{C}_{\text {org }}$ are most likely due to the difference in the ratio of plant-induced and macrophytic components of bottom sediment organic matter, the allochthonous sorghum presence, the photosynthesis intensity in the reservoir, and its productivity $[6 ; 7 ; 8]$.

According to the McKenzie model, the increase in primary production of the reservoir leads to the intensive use of ${ }^{12} \mathrm{C}$ in the photosynthesis process, due to the predominant fixation of the light isotope of carbon by a living substance [7]. Perhaps the heavy isotopic composition $\delta^{13} C_{\text {org }}$ of lake Tsagan-Tyrm bottom sediment can be explained by the fact that algae, which make a significant contribution to the organic matter of the bottom sediment, 
are under the salt crust in stagnant waters, which extremely depleted dissolved carbon dioxide (Table 1).

The value of the isotopic carbon composition of authigenic carbonate sediments in lakes of the same system vary within $\delta^{13} C_{\text {carb }}$ (from $-0.9 \%$ to $-7,3 \%$ ) for Tazheran (with the exception of carbonates in bottom sediment of the lake Tsagan-Tyrm $\delta^{13} \mathrm{C}_{\text {carb }}-23.6 \%$ ) and $\delta^{13} \mathrm{C}_{\text {carb }}$ (from $-11,0 \%$ to $-28,5 \%$ ) for the Baraba lake system. On the example of single system lakes, we can say that there is no direct dependence of carbonate carbon discharge on the degree of water mineralization. However, if we compare the lakes of the two systems with each other, then the general trend to facilitate the isotopic composition of authigenic carbonates in more fresh waters is revealed. Carbonates formed by chemogenic processes are similar to water isotopic values, i.e., with dissolved bicarbonate - ion reservoir. Nevertheless, bicarbonate dominates in most of the studied lake stagnant waters in the anaerobic environment, formed by the oxidation of carbon dioxide emitted by bacteriadecomposers in the mineralization of the original organic matter. This is proved by the numerous pseudomorphs of carbonates in mortmass macrophytes, cellular skeleton of algae and presence in all sediment samples from framboidal pyrite, starting with the border "water-bottom sediment". These data are also in agreement with the observed high productivity of organic matter in the waters of the lakes in summer and the significant organic matter content in the mass of their bottom sediments. The process of carbonate formation and biomass accumulation occurring in anaerobic conditions is accompanied by a noticeable alkalinization of water due to the removal of hydrogen ion in the formation of hydrogen sulfide (Table 1). Such carbonates have a lightweight isotopic composition $\delta^{13} \mathrm{C}_{\text {carb}}$, as they are formed in an environment with a high content of isotope-light $\mathrm{CO}_{2}$ from the decomposing organic matter $[9,10]$.

The comparison of the carbonates isotopic composition and bottom sediment organic matter of a separate lake, a lake system, between the systems of lakes did not reveal a general pattern. There are lakes in which the values $\delta^{13} \mathrm{C}_{\text {org }}$ and $\delta^{13} \mathrm{C}_{\text {carb }}$ correspond to each other. Presumably, it indicates the preferential chemical carbonates genesis and lack of carbonates recrystallization in the diagenesis process. There are lakes with different ratios of $\delta^{13} \mathrm{C}_{\text {org }}$ and $\delta^{13} \mathrm{C}_{\text {carb }}$ values in the sediments, occurring in both lake systems.

Isotopic studies of $\delta^{13} \mathrm{C}$ carbonates and organic matter of the lacustrine bottom sediments of the Tazheran and Baraba systems indicate two main mechanisms of authigenic carbonates formation: chemogenic deposition and biochemogenic deposition due to bacterial destruction of organic matter. The dependence of the $\delta^{13} \mathrm{C}_{\text {org }}$ and $\delta^{13} \mathrm{C}_{\text {carb }}$, the degree of water salinity is not revealed.

Work is done on state assignment of IGM SB RAS and by supported of the Russian Foundation for Basic Research № 18-45-540005 p-a

\section{References}

1. A.Yu Lein, M.D. Kravchishina, N.V. Politova, A.S. Savvichev, E.F. Veslopolova, I.N. Mitskevich, N.V. Ul'yanova, V.P. Shevchenko, M.V. Ivanov Lithology \& Mineral Resources, 47, 99-128 (2012)

2. A.M. Plyusnin, L.V. Zamana, S.L. Shvartsev, O.G. Tokarenko, M.K. Chernyavskii, Russian Geol.\& Geoph. , 54, 647-664 (2013)

3. V.D. Strakhovenko, O.P. Taran, N.I. Ermolaeva, Russian Geol.\& Geoph., 55, 1 1601169 (2014)

4. V.D. Strakhovenko, E.P. Solotchina, Yu.S. Vosel', P.A. Solotchin, Russian Geol.\& Geoph. 56, 1433-1446 (2015) 
5. V. Strakhovenko, E. Ovdina, E. Solotchina, G. Malov, Paleolimnology of Northern Eurasia: experience, methodology, current status and young scientists school in microscopy skills in paleolimnology (Kazan: Publishing House of Kazan University, 2018), 119-123

6. D.J. Hollander, M.A. Smith, Geochim. Cosmochim. Acta, 65, 4321-4337 (2001)

7. J. A. McKenzie, Chemical Processes in Lakes (Wiley Interscience, N.Y., 1985) 99118 ,

8. O.P. Taran., V.V. Boltenkov, N.I. Ermolaeva, E.Yu. Zarubina, I.V. Delii, R.E. Romanov, V.D. Strakhoveko, Geokhim., 3, 269-279 (2018)

9. W. Fushun, W. Guojiang, L. Congqiang, X. Siqin, Chin. J. Geochem, 21, 186-192 (2002)

10. Ya.E. Yudovich, M.P. Ketris, Biosphere, 2, 231-246 (2010) 